Instructions for authors, subscriptions and further details:

http://rasp.hipatiapress.com

\title{
"This Brings you to Life" The Impact of Friendship on Health and Well-being in Old Age: the Case of La Verneda Learning Community
}

Susana León-Jiménez

Universitat de Barcelona

Date of publication: July $30^{\text {th }}, 2020$

Edition period: July 2020 - January 2021

To cite this article: León-Jiménez, S. (2020). "This Brings you to Life" The Impact of Friendship on Health and Well-being in Old Age: the Case of La Verneda Learning Community. Research on Ageing and Social Policy, 8(2), 191-215. http://10.4471/rasp.2020.5538

To link this article: $h t t p: / / d x . d o i . o r g / 10.447 /$ rasp.2020.5538

\section{PLEASE SCROLL DOWN FOR ARTICLE}

The terms and conditions of use are related to the Open Journal System and to Creative Commons Attribution License (CCAL). 

pp. 191-215

\section{"This Brings you to Life" The Impact of Friendship on Health and Well-being in Old Age: the Case of La Verneda Learning Community}

\section{Abstract}

Friendship has been studied along centuries, since ancient times to presentday, as the basis of the social cornerstone, present at all stages of the lifespan and belonging to the world of truthful sentiments. Benefits of friendship on health have been demonstrated. Less is known about the role of friendship on seniors. The aim of this case study has been to show how the end friendship developed in an adults' school operating for more than 40 years in Barcelona is having a positive impact on the well-being and health of their participants. Through the communicative focus group, we have deepened in the trajectories of some of the school participants. The results show how participation in the school and the dialogic gatherings have contributed to the emergence of a noninstrumental friendship feeling and to consider an impact on the perceived general wellness and health and an improvement of their life quality. It is discussed how this research provides more elements to the existing literature. More research on how other communitarian environments have similar effects on this population, or on the impact of these dialogical spaces in the development of end friendships in other stages of the life cycle would be of interest.

Keywords: School as Learning Community; social impact; friendship; wellness; seniors 


\section{"Esto te Da la Vida" El impacto de la Amistad en la Salud y el Bienestar en la Tercera Edad: el Caso de la Comunidad de Aprendizaje La Verneda}

\section{Resumen}

La amistad ha sido estudiada durante siglos, desde la antigüedad hasta nuestros días, como la base del pilar social, presente en todas las etapas de la vida, y propia del mundo de los sentimientos honestos. La literatura ha demostrado los beneficios de la amistad en la salud, pero su papel en personas de la tercera edad aún es un área que requiere más exploración. El objetivo de este estudio de caso es mostrar cómo la amistad sentimental ${ }^{1}$ desarrollada en una escuela de personas adultas que lleva más de 40 años funcionando en Barcelona está teniendo un impacto positivo en el bienestar y salud de sus participantes. A través del grupo de discusión comunicativo, hemos profundizado en las trayectorias de algunos participantes de la escuela. Los resultados muestran cómo la participación en la escuela y las tertulias dialógicas han contribuido a la emergencia de una amistad no instrumental con impacto en el bienestar general y la salud, y una mejora de su calidad de vida. Más investigaciones acerca de cómo otros ambientes comunitarios suponen efectos similares en esta población, o sobre el impacto de estos espacios dialógicos en el desarrollo de amistades sentimentales en otras etapas del ciclo vital serían de interés.

Palabras clave: Comunidad de Aprendizaje; impacto social; amistad; bienestar; vejez 


\section{León-Jiménez - This Brings you to Life}

$\mathrm{F}$

riendship has been widely studied along centuries, since ancient times from classical philosophers as Kant, Plato or Aquinas to present-day researchers on different disciplines (Reisman, 1979; White, 1999; Zamora, 2009). It is considered a feeling (Tabak et al., 2012; Thomson \& Crocker, 2013) that can be nearly found at all stages of the lifespan (Bukowski et al., 2009), and that is at the basis of the social cornerstone (Aquinas, 2001; Shushok, 2008; McCall et al., 2017), belonging to the world of truthful and altruist sentiments (Reisman, 1979), such as love, union, trustworthiness or solidarity (Aristotle, 1999; Aquinas, 2001; Alberoni, 2006; Thomas, 2013).

Definitions of friendship are as diverse as wide is the research on it, having some underlying common elements such as reciprocity, appreciation among participants and election (Leibowitz, 2018). One of the best-known classical conceptions run today is the Aristotelian's one. The Aristotle's inquiries on friendship are considered the most extended along the history of the western philosophy (Benetatos, 2013), and as it appears in Ethics, Magna Moralia, Eudemian, or Nichomachean, the friend is described like "other self" (SternGillet, 1995). After many dissertations, Aristotle came to distinguish among three kinds of friendship: friendship based on utility, friendship based on pleasure and friendship based on goodness, being this last one considered the perfect friendship as it is grounded in excellence, balance and virtue and the friend is loved not purposeful and circumstantially, but on the person oneself (Fortenbaugh, 1975).

Aquinas, from a theological discourse referred to the Aristotelian dissertation of friendship in Nicomachean Ethics (Jones, 1987), also discusses friendship along his work (Schwartz, 2007). To him, friendship and love are closely linked, so he defines friendship as a kind of love fulfilling three features: it is a benevolent love, a mutual love and a love founded on a communicatio (Bobik, 1986). He also makes a distinction among kinds of friendship, differentiating the love of concupiscence, referred to the friendship addressed in the interest for the good the other person brings -which corresponds to pleasure or utility friendships in the Aristotelian's conception; and the love of friendship -referring to the Aristotle's perfect friendship-. Lastly, Aquinas refers to a charity form of friendship, which would correspond to the purest form, being undertaken because of love towards God (Ney, 2006). 
Cicero has also been renewable for his essay on friendship in Laelius de amicitia, where he praises this feeling as one of the best and most durable possession of a human being, characterised by some features such as love, honesty, empathy or good will, among others. He also opposed friendship to utilitas and underlined the importance of choosing friends well (Cicero \& Powell, 1990).

Contemporary approaches about the classification and study of friendship have been developed mostly underpinned on those classical conceptions. Thus, the aforementioned divisions can be summarised in two general types, referring as a criterion the purpose of the friendship relationship (Badhwar, 1993): instrumental friendship and end friendship. The first one would correspond to the friendship that has been built with a functional aim, and a common interest, which may be professional, socio-economical, religious, ideological, hobbies, etc., in a sum, the ones you choose to fulfil an instrumental objective. The end friendship, which may be a synonym of the Aristotle's perfect friendship, being the one whose main aim is not to accomplish a particular interest, but the feeling itself (Badhwar, 1993). Yet, although an instrumental friendship based on mutual interests can be the beginning of a sentimental friendship, there is agreement on the fact that this overlapping of interests, even values, is not enough, and that feelings such as love, mutual trust, self-disclosing bond (Thomas, 1987; 2013) are required.

The value of friendship is universal and common to every human being across the world (Thomas, 2013). Friendship has been studied as the greatest predictor of life satisfaction (Putnam, 2001) and as a primary source of happiness, both in strong economies and in those backgrounds of scarcity (Lane, 2000). Thus, the benefits of friendship have been demonstrated, from childhood and adolescent periods, supposing bullying protection (Bollmer et al., 2005; Kendrick et al., 2012), psychosocial development (Dishion et al., 2001; Vitaro et al., 2009) or adult adjustment (Bagwell et al., 2002), to later stages impacting on health, longevity, happiness, or on reducing mortality (Sabin, 1993; Rodriguez-Laso et al., 2007; Anderson \& Fowers, 2020). As obtained in the Harvard Study of Adult Development -the longest longitudinal study on variables that predict health and well-being-, the factor that led to healthier people and a longer and happier life was the quality human relations (Vaillant, 2003; Racionero, 2018). 


\section{León-Jiménez - This Brings you to Life}

Although a growing research is focusing on those positive effects of relationships on elderly people's health, more literature on the role of social relationships, and specifically friendship, on seniors' well-being and quality of life is of interest (Wilhelmson et al., 2005). According to literature, along the third age, some psychological factors, such as loneliness, exert a great influence on the quality of mental and physical life, with negative consequences on health, associated with higher risk of mortality (Steptoe et al., 2013). Being so, the quality relationships are of great importance at this stage of life, even in primary prevention, in clinical terms (Gerino et al., 2017). However, despite public recognition of the importance of health conditions in relation to feelings of loneliness or depression in the elderly, this remains an area not sufficiently explored from the scientific literature (Djukanović et al., 2015).

Thus, retirement and old age can suppose a risk for loneliness, social isolation or weak social networks (Cornwell \& Waite, 2009). According to the theory of the psychosocial development founded by Erikson, lives are divided into stages in lifespan, where a crisis occurs in each of them confronting the individual needs with the social ones. The eighth stage corresponds to maturity (old age), where integrity, despair and wisdom are the main characters of the crisis. It is the time when people contemplate and balance their lives, evaluating success and productiveness, where satisfaction leads the virtue of wisdom and completeness, and failure in despair (Erikson, 1982). Integrity, the detailed management of all activities, with all the attention for a well lived day, is developed with the sense of completeness, and it promotes contact with people. Whereas in adulthood, many instrumental friendships took place, at old age, sometimes, a void can be produced when the instrumental activities fade. Nevertheless, at maturity, everybody and everything matters more than ever before, and any meeting is special and rewarding. Love and friendship blossom, and the prettiness of the relationships warms the heart (Erikson \& Erikson, 1998).

Many elderly people, in the search for those rewarding relationships, look for different activities or alternatives for social participation and engagement (Mollenkopf, 1997). Some of the activities offered in Barcelona, which have a particular success, are those happened in the adults' school La Verneda Learning Community. School participants have many diverse economic, ideological or professional backgrounds and no instrumental interests are 


\section{RASP - Research on Ageing and Social Policy, 8(2) 197}

given. The purpose of this study is to approach some senior participants' voices in order to deepen in how relationships are given here, the friendship developed and how they feel it has impacted in their health and well-being.

\section{Method}

\section{Context}

Located in a civic centre, and sharing the building with other social spaces, La Verneda-Sant Martí Adult School (Barcelona) is the first Learning Community in the world (Sánchez, 1999; Elboj et al., 2003; Folgueiras, 2011). It was born in 1978, as a result of an educational project shared between the neighbourhood and the school, with the aim of responding to the academic demands of the inhabitants of the working-class district that shares name with the school, in response to the deficiencies that were hindering their access to the labour market (Aubert et al., 2016). Resulting in academic and social impact, the school became an international benchmark (Valls \& Munté, 2010) and a precursor to the transformation of more than three thousand schools around the world ${ }^{2}$.

Since its inception, the school aims to provide the best possibilities to as many people as possible regarding educational, social and cultural activities, diversified in accessible time slots that cover from morning to night, the seven days of the week (Folgueiras, 2011). Based on an egalitarian and democratic school model (Ríos, Herrero \& Rodríguez, 2013) built on the principles of dialogic learning (Flecha, 2000), the school is organized from mixed commissions, with the presence of various groups, where all the educational community participates, debates and decides issues that concern the centre (Burgués, 2015).

Regarding the activities undertook at the school, there are training courses, such as literacy; basic qualification; university entrance courses; job training; and a diversity of workshops. These activities are put into practice through the most internationally implemented Successful Educational Actions (SEAs), which are those educational actions that have demonstrated to foster social and academic success wherever they are applied (Flecha, 2015). Among the most implemented SEAs in the school, we can find the Interactive Groups, or the Dialogical Gatherings (DGs) (inter alia, literary, cybernetic and feminist) ${ }^{3}$, both originated in the school (Folgueiras, 2011; Aguilar et al., 2010). Special attention deserves the DGs, as it was the very first activity implemented together with the birth of the school and where participants of the study have 


\section{León-Jiménez - This Brings you to Life}

participated the most. With a proved transformative power on the disadvantaged people's lives (Soler, 2015), DGs are a kind of SEA based on the discussion of classical literature, art/music masterpieces or scientific works, whose participants' deep interpretations drive to a dialogical construct of knowledge, and the transformation of their personal lives and learning processes (Serrano et al., 2010; Barros del Río et al., 2020).

The School's transcendental social and educational work has been the subject of reports in the media and constant recognition, such as the award for democratic commitment, solidarity or equity, or the Gold Medal for Civic Merit recently granted. The international scientific community has also recognised its impact, finding the praises of authors such as Commings (Director of the Center for Literacy Studies and Adult Learning, Harvard University), Rodriguez de Mello (Federal University of Sao Carlos, Brazil), Compton-Lilly (University of Wisconsin); Pun Ngai, (Hong Kong Polytechnic University) or Wells (University of California), among others. Constant feedback with scientific evidence is materialized in the continuous participation of the school in various European projects and in collaboration with many associations and centres in the area of education in Europe.

As a result of this doubly committed work towards scientific evidence and social improvement, impact results are generated, amongst them: free education for so many people, increase of the number of social services, the renewal of the boulevard or the metro service. Likewise, the impact transcends through collaboration with other entities, focusing on spreading adults' mobilisation and concrete actions ${ }^{4}$.

\section{Participants}

Six people, two men and four women, over 70 years old have participated in this study. Two of them have been involved in this Learning Community since the beginning of its creation -more than 40 years ago-; three people for more than 30 years, and the last one, for 15 years. All these people have participated in the first instance as students and, later, as volunteers and other roles (see Table 1). 
Table 1.

Participants' data regarding their involvement in the school

\begin{tabular}{|c|c|c|c|c|}
\hline Participant & Age & Gender & $\begin{array}{c}\text { Participation } \\
\text { beginning }\end{array}$ & Main roles \\
\hline Violeta & 74 & Women & 1978 & $\begin{array}{l}\text { Student, moderator in dialogic } \\
\text { gatherings, vice-chair }\end{array}$ \\
\hline Gabriela & 80 & Women & 1979 & $\begin{array}{l}\text { Student, moderator in dialogic } \\
\text { gatherings, chair, board member }\end{array}$ \\
\hline Alejandra & 84 & Women & 1988 & $\begin{array}{l}\text { Student, teacher and class } \\
\text { representative }\end{array}$ \\
\hline Vicent & 86 & Man & 1988 & $\begin{array}{l}\text { Student and administration } \\
\text { collaborator }\end{array}$ \\
\hline Sofía & 70 & Women & 1990 & $\begin{array}{l}\text { Student and school canteen } \\
\text { responsible }\end{array}$ \\
\hline Federico & 81 & Man & 2003 & $\begin{array}{l}\text { Student, moderator in dialogic } \\
\text { gatherings, teacher }\end{array}$ \\
\hline
\end{tabular}

\section{Design}

This study was conducted through the Communicative Methodology (Gómez et al., 2011). It has been recognized by the European Commission as the convenient approach for working with vulnerable groups for the sake of social impact, and whose main premise is the inclusion of the arguments of the participants involved through equal and intersubjective dialogue, free of interpretive hierarchies, in all phases of research. This fact nurtures, enriches and develops the scientific contributions made by researchers (Gómez et al., 2012; Flecha \& Tellado, 2015). Specifically, in adult education research, the breaking of the methodological gap -between the researcher and the research subject- and the recognition of cultural intelligence result in a social, political and scientific impact of research that motivates the transformation and prevention of exclusion (Flecha \& Tellado, 2015).

With the aim to explore in detail the case of La Verneda school, a case study design was chosen, as it is considered the most appropriate format to analyse profoundly an exclusive situation, not focused on generalisation, but to enhance understanding of that case (Stake, 2005). 


\section{Data Collection and Analysis}

Data was collected at the end of June 2019, through a communicative focus group (Gómez et al., 2012), a suitable technique when studying a group of people who are part of a community in usual social interaction, and intended for reaching an in-depth understanding and collective interpretations of social realities, while researcher contributes actively to the discussion from the science perspective for the sake of social transformation (Puigvert et al., 2012).

Information on their life trajectories was gathered, focusing on three different data blocks: (a) school participation experience (beginning, activities where they were involved, perception on how these activities have changed their life); (b) friendship (relationship with other school participants, friendship in the school, how the school actions have contributed to friendship, amongst other questions); (c) personal wellness in third age (health, self-confidence, how friendship have impacted their perceived wellness, inter alia); and (d) other possible issues that participants estimate important to consider. Despite the mentioned blocks of content, the discussion was conducted in a semi-structured way, while some questions were launched to the group in order to address discussion to the topic of the research.

The session was audio-recorded and later transcribed. After the analysis, three categories emerged: (a) experience at the school, (b) friendship and other feelings emerged in the participation, and (c) wellness and health improvement. These categories correspond to the three results' sections presented below.

\section{Results}

\section{A Whole Life in The School: "Once You Try, You Come Again"}

When participants were asked about their experience at the school, the ongoing involvement was firstly highlighted. Some people underlined how they were in the school since its inception, while others for thirty to fifteen years: "I came to learn in this school at the outset, in 1979" (Gabriela), "I was here, and here... And now I have been for 28 years here" (Sofia), "I have been here for 30 years" (Alejandra). And participants claimed that the reason why they continue for such a great time participating in the school is because, as they argue "once you try the experience, you come again", overcoming even personal circumstances which hinder attendance. It is the case of Federico, 
who came to the school for learning ICT and, after 5 years of uninterrupted participation, he had to stop due to personal reasons, coming back soon to school and starting to teach about smartphones and participating in European research projects:

I came here to school for ICT lessons. I did not know [how they worked] and I was taught by those who were volunteers. After 5 years, I could not attend for one or two years due to personal reasons. Then I came here [to school] again and picked up the ICT courses and then, about 7 years or so ago, I started to be interested in smartphones and started to teach (...). I have participated in some European programs here [in the school], I have also collaborated on that (Federico).

Violeta remembers that she participated from the beginning, since the creation of the Dialogical Literary Gatherings (DLGs). She says that they went to literacy classes and, after that, they had the DLGs, reading and analysing poetry from the classic book Gipsy Ballads, by Federico Garcia Lorca. After that, she continued until today participating in the school, attending classes and DLGs:

"I have participated from the outset [of the school], since they [dialogical literary gatherings (DLG)] began. (...) By the time classes ended, at 7 p.m., DLG started, so I went there, where they took place. (...) The first book we read, which I remember well, was Gypsy Ballads and well, we analysed several poems... I continued [attending school], and I was going up, doing undergraduate lessons and graduate certificate classes. (...) I had to be one or two courses without attending school, but later, when I already graduated, I re-joined again and there I continued." (Violeta)

The sense of community and the solidarity experienced in La Verneda contribute to the sustainability of the school. Thus, participants keep on involving with different roles in the school resulting from the gratitude for all the solidarity experienced by them and the community awareness adopted. Violeta expresses that after being on a course of ceramics, she started to teach ceramics, because she felt a commitment: as she had learned for free, she should offer what she had, her knowledge, for other people in need who wanted too. In the case of Federico, he feels that the neighbourhood is linked to the school, and vice versa, and that the role of participants is to contribute and help to the community: 


\section{León-Jiménez - This Brings you to Life}

"I graduated [taking lessons at the school] and then I started to enrol in crafts [at the school]. I went to a ceramics course, and then I started to teach ceramics: what I learned, then I taught it. So, you feel it like a commitment: you come to learn for free, so our obligation is also to contribute in return with something that people cannot afford." (Violeta)

"I have already leafleted flyers for the school, that is, I move from here, to there... that is to say, I move around the neighbourhood, because what I want is the neighbourhood, because you see that there is a relationship with everything [referring to the link between the school and the neighbourhood](...). It is what we, the volunteers, do: what they taught us is what we teach now." (Federico)

That solidarity and the communitarian lifestyle experienced in the centre has evolved to impacts achieved, from neighbourhood transformations to international prospect. According to participants, due to the communitarian attitudes, they have achieved great transformations in their environment. The first and most important one was the achievement of the physical space where the school is located, a civic centre: "This civic centre has been the neighbours' struggle" (Sofía).

They explain how the communitarian proceeding has helped to gain the participation of more and more stakeholders in the school. In the first dialogue sequence, some participants tell the anecdote of the $15^{\text {th }}$ anniversary of the school, and how they mobilise in order to receive supplies for the party celebration. In the second statement, it is Federico who tells another example of this communitarian way of action, referring to the material donated by a university for the school, such as furniture and computers:

P1: [Some years ago, when they celebrated a public holiday with a party] We went to the market, for the festivity, in order to ask for some chestnuts, when the season of chestnuts was.

P2: That happened in the $15^{\text {th }}$ birthday of the school. We used to do a big party, there was no money to buy... so we wrote a letter addressed to the market headmaster, and she gave as all the chestnuts as a present, for the Saint Martin festivity, and lots of wine bottles!

P3: They brought so many bottles of wine that we had enough for two or three more parties [laughs].

Here it [functioning] is: 'something from here, something from there...' tables, computers, etc. have been donated from Pompeu Fabra [University]. Some girls [from the university and participating 


\section{RASP - Research on Ageing and Social Policy, 8(2) 203}

at the school] told us: 'computers and tables are for you if you come to collect them'... In other words, everyone collaborated... and is collaborating currently! (Federico)

The significance of community actions and procedures have had an impact beyond the school, the neighbourhood and the city. Continuously, the school takes part in European projects, seeking to provide useful evidence for the international scientific community. Thus, participants remember the participation in different programs with entities from other countries, as Federico, who states that the school has always intended to impact abroad, not merely act in its environment, but to take action internationally:

[In ICT] we participate on a project in which we communicate with Italy, with France and with England. (...) Things have always been done here with a focus on abroad. (...) It is not a school that always stays here, but it is a school that has always looked at that direction, doing things facing the outside, that is what we have intended to do..." (Federico)

Participation in those international programs supposes also an impact on participants' learning. Violeta explains the moment in which the school participated as a partner in a European Project about DLG and the most representative for her was the fact that despite they were from different countries or social and cultural contexts, all of them expressed the same feelings:

"A very interesting one [participation in EU projects] (...) we read a book ourselves, and then there were some coordinators, there was [partners] from the Czech Republic... I think France and Denmark too. (...) All of us worked on the same book... so the important thing about this was that all the countries, even having a different culture and a different economy, basically we all thought the same thing (...), it means that the feelings are the same everywhere. It was a very nice gathering that we did." (Violeta)

\section{Emergence of Strong Relationships and Friendship}

Within this framework of community actions and activities that take place at school, the emergence of feelings of friendship is clearly evidenced. From the beginning of the focus group, the participants greet each other cheerfully, want to sit together, make jokes, and during the course, as they share their 


\section{León-Jiménez - This Brings you to Life}

experiences of improvement, everyone rejoices, congratulates and celebrates the other's achievements. They are experiencing lasting and deep friendships, as Violeta acknowledges from the very beginning, affirming that the bonds among the school participants are very tight: "Human relationships are very deep in this centre, it is so obvious" (Violeta).

In the development of dialogues and anecdotes of their experiences in the school, participants usually point out this importance of the tight social relationships experienced. Shared conceptions of the importance of these relationships have become the cornerstone of the school. Thus, they feel very close one another, they focus on human relationships as the most important, and this is the reason why they use the Three Musketeers' motto: "One for all and all for one". They even state that they have an implicit norm at the school, which is: unkind people and those who demonstrate a lack of solidarity, cannot continue at the school. In the dialogue line, they expressed it like that:

P1: Here, we are like peas in a pod, that is for sure.

$\mathrm{P} 2$ : We have always been like peas in a pod, yes.

P3: Here, everyone is very kind, because who is not, cannot be here.

P1: We ourselves do be able to drive us out, if we are not "one for all and all for one".

P3: If they do not practise the ideology, which is to help us each other, and so on.

P4: Human relationships... That is what really matters at the end.

Along the discussion, participants laugh and celebrate that the fact that their passage through the school has developed friends in the whole neighbourhood. As they express, people who have participated in the school is renowned, so when they walk along the neighbourhood boulevard, they meet and are beloved by many people, to the extent that they avoid, as they joke, to frequent the common streets of the neighbourhood:

P1: Well, whoever has done something here at the school cannot walk down the street [laughs]. I no longer walk around Guipúzcoa street.

P2: You can't go out on the street quietly.

P3: I have a friend [from the school] and we together go out for a walk... and even we have to cover our faces too! [laughs].

P4: They are the human relations that we have here...

P5: My husband and I sometimes go for a walk and he says, "we are going down the other street, because here... even cats know you!" [laughs]. 


\section{RASP - Research on Ageing and Social Policy, 8(2) 205}

Thus, one of the elements that they stand out the most is the diverse nature of the friendships they develop in the school, pointing to intergenerational friendships, and with a diversity of groups. Violeta emphasises this fact underlining how her relationships and the solidarity experienced with young people in the school have developed tight links and feelings expressed through tokens of affection. In the same way, in the second statement Alejandra expresses the relationship emerged with a girl with some learning difficulties to whom she adapted teaching in order to make it more accessible, and how after many years, this girl still appreciates it and shows her with hugs whenever they meet:

"A very interesting thing I would like to point out: there is the stereotype, or the theory that young and old people do not understand each other. Well, I have shared many modules with young people, which has been great because each of us has helped each other in what we knew, and then you see them on the street... and when they see me... they hug me a lot!" (Violeta)

"A little young girl in a wheelchair came to me [to the classes where she taught], mother and daughter came. (...) I began to teach her in a different way (...) Now when she sees me on the street, she hugs me!" (Alejandra)

The power of the friendship developed in the school even supposed a reason to get involved, to keep going, and to keep learning. For Violeta, who lost her husband, the school supposed more than just meeting people, but to make friends, what have let her keep attending to the school. Alejandra also told how she and other participants who became friends keep doing DLGs despite the time did not suit to their availabilities, just because of the love they feel for each other and the "need" to be in touch constantly:

"I became a widow at the age of 51 and from there [didn't stop participation in the school]. (...) I want to say that it is also a way of making friends (...) this is much more than just meet people" (Violeta).

"I coordinated a DLG from 3 to 5 p.m., and I have been for about 8 years. It [the timing] wasn't good for the participants, neither for me, but as all of us loved each other very much we continued coming. (...) From 3 to 5 p.m. is a very bad time for everyone and even for me, but well, as we already had that tie... This is the truth." (Alejandra). 


\section{León-Jiménez - This Brings you to Life}

\section{Impact on Health and Well-being. Impact on Life}

After the life balance carried out throughout the focus group, where participants have made a complete review of their experience at school, the most personal evaluations emerge. According to the participants, the friendships and relationships undergone in the school have supposed a double impact on health: on the one side, in mental health through an improvement of their self-esteem, and on the other side, on physical health, as they explain in their stories.

The participation in the school, and the activities linked to it, supposes a space of recognition and empowerment that directly impact their personal satisfaction and self-confidence. Federico tells some anecdotes reflecting on how the enthusiasm of learning something you were not able to do before and to demonstrate that you can do it have improved their feeling of self-worth. He very pleased tells the episode about how surprised and amazed the project partners from other institutions are when they visit the school and see the senior people teaching. By the other hand, Gabriela expresses proudly the anecdote that she were invited to make a speech in the university telling her experience in the school, and after the speech, two full professors asked her very surprised if she really was illiterate, because she have worded pretty well:

"Enthusiasm. (...) That is what happens now with computing. It is said that we [seniors] are functionally illiterate. But when you discover that you can understand, that you can do it if you want... you discover how much you actually worth! (...) Once in an Erasmus from a European project in Germany, they were astonished to see that I could teach, and they asked me to do a class there, like the ones I do here [in the school]. In other words, people are not used to see a centre like this for older people who teach everything, a school like this... (...) some Japanese [partners] came [to visit the school] and was completely astonished, greatly surprised, uh! It is obvious, they entered a class, they saw me giving one [class], then they entered another [class], they saw another senior... they were astonished!" (Federico)

"They invited me to give a lecture at the university (...) with two full professors, one on each side, and one of them, looking at me when I was speaking, asked me 'and did you say that you don't know how to read or write?'. I answered 'no'. And he said 'well, you have worded superbly'. The room was full to the brim" (Gabriela). 
Participants acknowledge the usefulness of their engagement in the school. According to their statements, participants' contribution in the school has supposed a great help to many people, especially for people in need, feeling that they still have a lot to offer the community: "We have been very helpful for people with problems" (Gabriela); "And we have to contribute much more yet!" (Vicent).

Participants highlight that the friendship and relationships experienced in the school has supposed a very positive influence on their life in general, and on their health and well-being, in particular. They stress the fact that they have always tried to organize their personal trajectories in order to fully participate in the movement of the centre, because, as participants acknowledge, "this brings you to life!" (Violeta):

"I had my two children and my husband, too, but I managed in order to have time and being able to come to teach (I taught in the afternoon)... and I came here [the school] and felt much better than I am now [she cannot participate currently]. This wakes you up!" (Alejandra)

This consideration of participation and dedication to school as a cause of the feeling of fullness and life experienced leads them to share and invite other friends to become part, since it becomes experienced as a therapy in the face of loneliness. Federico, for instance, came to the school when he lost his wife, and it breathed life to him, so he recommended to his friends:

"When I became a widower (...) I came here [to school] and I surrendered here and that has breathed a lot of life to me... it has brought me a lot, a lot of life, and I meet many widows and widowers. (...) There is a lady, who has been a widow for six months and I recommend her 'go here, go there', why? Because it was very good for me ... and [also recommended] to a friend of mine who also became a widower a few months ago, because it was very good for me. That is, this is my therapy!" (Federico)

These "therapeutic" effects and the impact of the actions experienced through the friendship and relationships enjoyed in the school towards their quality of life transcend to the point of becoming known by the neighbourhood healthcare personnel, who recommend the participation in the school as a treatment for various problems, including emotional ones:

"Even the doctors [recommend the school]! Once I went to the doctor, I don't go much because I am in good health (...) and he explained to me that they often referred people with problems to school. (...) Many 
times, people go to the doctor... or because they feel alone, and they [doctors] often referred them to school to improve people's health" (Violeta).

\section{Discussion}

"A school where people dare to dream". This is the motto of the school, which illustrates the way of action of people who goes a step forward and makes possible that a learning community become a life community, a secure place where diversity coexists, and a friendship point of meeting. In the ceremony of the Gold Medal for Civic Merit (a maximum distinction granted by the city council to the school participants for the work and actions towards the community life) some participants expressed that "it is a welcoming atmosphere where friendship is easily created", "the school should be a little map of the world, I would love that what happens here was also outside" or "it [the school] struggle to improve people's lives, and I hope it will be this way forever'. It is concluded that, when referring this school, two notions appear: a) the importance of social relationships and friendship in the school, and b) its influence on the improvement of people's lives and wellness. Thus, as it has been shown in the results section, the adoption of the Three Musketeers motto for describing their way of functioning, the solidarity as a rule, or to consider themselves as "peas in a pod", inter alia, evidence the quality of the relationships experienced and explain the impact reported in their health and well-being.

"The real friendship is like fluorescence; it shines better when everything has darkened" (Rabindranath Tagore). Participants in the study, which are retired and living the maturity stage (Erikson, 1982), implying a review of their lives and a balance of what really matters, can find in this school the option for experiencing healthy social relationships and a non-interest-based friendship, which may be both intergenerational or intercultural, without instrumental concerns. In the words of a participant: "Human relationships... that is what really matters at the end". Thus, participants have explained various arguments that reflects this clue, and how the end friendship experienced in the school has comforted and company them in their utterly complicated moments, such as widowhood.

"The soul forgets all the sufferings when the sadness is in company and has a friendship that comforts it" (William Shakespeare). The transcendent impact of the friendship experienced in the school is so significant that some doctors recommend their patients to involve in the school in order to overcome 
loneliness, and for improving their health, as a participant stated. As it is shown, this school is sometimes considered like a therapy, not only for the participants' general well-being, but also because their self-perception improves, they say they feel worthwhile, and because this participation "breathes life to them", demonstrating what Aristotle (1999) asserted when he wrote that friendship is the most essential in life.

"Don't walk behind me, I may not lead. Don't walk in front of me, I may not follow. Just walk beside me and be my friend" (Albert Camus). Participants have shown to experience a sort of a perfect friendship, a friendship that do not search for status or self-centred positions, that belongs to good and equal people who wishes the best each other, being the feeling of friendship the end above all (Badhwar, 1993; Aristotle, 1999). These women and men have participated in the school with different roles. Some of them have been chair, vice-chair or administrator of the school, but no power comments, claims or positions have been evidenced; on the contrary, solidarity, dialogue, union and love are the premises they highlight in their narratives. The school operates driven by a dialogic leadership, a process where all the community members, through dialogue, develop and contribute to leadership practices, working together for the sake of the improvement of the whole school, their contexts and their lives (Redondo-Sama, 2015). Some examples of the transformations attained through this dialogic leadership in friendship is the achievement of the school building, but also their significant learning progresses, or the continuous participation in European research projects.

This research runs more elements to the already existing literature about elderly on overcoming loneliness, social isolation, poor social networks, and the risky consequences associated with it. It would be of interest to delve on how other communitarian environments have similar effects on this population; and provide further evidence on the positive impact of these dialogical and communitarian spaces in the development of end friendships in other stages of the life cycle.

Shakespeare, Tagore and Camus have given voice to the concluding remarks. These are just some of the classic authors that participants have read and met through the participation in the school and in the DLGs. Whether through the readings -where participants have the opportunity to approach universal and deep values and feelings-, or because of the ongoing involvement in the school -permeated by solidarity, the sense of community 


\section{León-Jiménez - This Brings you to Life}

and strong bonds-, participants are having the opportunity to experience an end -or perfect-friendship beyond any kind of instrumental interest, which leads to an improvement of their lives, the sense of well-being and, in essence a better mental and physical health.

\section{Notes}

1 The term "amistad sentimental" has been used in the Spanish version of the abstract as equivalent to "end friendship" concept, due to suitability reasons.

${ }^{2}$ Information extracted from the official websites of Schools as Learning Communities and Latin-American Schools as Learning Communities (Natura). Comunidades de Aprendizaje, https://comunidadesdeaprendizaje.net/ and Comunidade de Aprendizagem, https://www.comunidadedeaprendizagem.com/, respectively.

${ }^{3}$ Information extracted from La Verneda Learning Community website. Escola d'adults de la Verneda, http://www.edaverneda.org/edaverneda8/es/

4 Information extracted from La Verneda Learning Community website. More detailed information in Escola d'adults de la Verneda: Reconocimiento, http://www.edaverneda.org/edaverneda8/es/node/17; Escola d'adults de la Verneda: Què diuen de l'escola, http://www.edaverneda.org/edaverneda8/es/node/155; and Escola d'adults de la Verneda: Proyectos europeos, http://www.edaverneda.org/edaverneda8/es/node/58

\section{References}

Aguilar, C., Alonso, M. J., Padrós, M., \& Pulido, M. Á. (2010). Lectura dialógica y transformación en las Comunidades de Aprendizaje. Revista Interuniversitaria de Formación del Profesorado, 24(1), 3144. https://www.redalyc.org/pdf/274/27419180003.pdf

Alberoni, F. (2006). La amistad: aproximación a uno de los más antiguos vínculos humanos. Gedisa.

Anderson, A. R., \& Fowers, B. J. (2020). An exploratory study of friendship characteristics and their relations with hedonic and eudaimonic wellbeing. Journal of Social and Personal Relationships, 37(1), 260280. https://doi.org/10.1177/0265407519861152

Aquinas, T. (2001). Suma de teología. Biblioteca de autores cristianos. Aristotle (1999). Nicomachean Ethics. Batoche Books.

Aubert, A., Villarejo, B., Cabre, J., \& Santos, T. (2016). La Verneda-Sant Martí Adult School: A Reference for Neighborhood Popular Education. Teachers College Record, 118(4).

Badhwar, N. K. (Ed.). (1993). Friendship: A philosophical reader. Cornell University Press. 
Bagwell, C., Schmidt, M., Newcomb, A., \& Bukowski, W. (2002).

Friendship and Peer Rejection as Predictors of Adult Adjustment. New Directions for Child and Adolescent Development, 2001(91), 25. https://doi.org/10.1002/cd.4

Barros-del Rio, M. A., Álvarez, P., \& Molina-Roldán, S. (2020). Implementing Dialogic Gatherings in TESOL teacher education. Innovation in Language Learning and Teaching, 1-12. https://doi.org/10.1080/17501229.2020.1737075

Benetatos, S. (2013). Aristotle's Notion of Friendship. In D. Caluori (Ed.) Thinking about Friendship: Historical and Contemporary Philosophical Perspectives (pp. 11-29). Palgrave Macmillan.

Bobik, J. (1986). Aquinas on communicatio, the foundation of friendship and caritas. The Modern Schoolman, 64(1), 1-18. https://doi.org/10.5840/schoolman19866411

Bollmer, J. M., Milich, R., Harris, M. J., \& Maras, M. A. (2005). A friend in need: The role of friendship quality as a protective factor in peer victimization and bullying. Journal of interpersonal violence, 20(6), 701-712. https://doi.org/10.1177/0886260504272897

Bukowski, W. M., Motzoi, C., \& Meyer, F. (2009). Friendship as process, function, and outcome. In K. H. Rubin, W. M. Bukowski, \& B. Laursen (Eds.), Social, emotional, and personality development in context. Handbook of peer interactions, relationships, and groups (pp. 217-231). The Guilford Press.

Burgués, A. (2015). Learning in school for tomorrow jobs. Intangible Capital, 11(3), 458-484. https://doi.org/10.3926/ic.656

Cicero, M. T., \& Powell, J. G. F. (1990). On friendship: The dream of Scipio. Liverpool University Press, Aris \& Phillips.

Cornwell, E. Y., \& Waite, L. J. (2009). Social disconnectedness, perceived isolation, and health among older adults. Journal of health and social behavior, 50(1), 31-48.

https://doi.org/10.1177/002214650905000103

Dishion, T., Poulin, F., \& Burraston, B. (2001). Peer Group Dynamics Associated with Iatrogenic Effects in Group Interventions with High--Risk Young Adolescents. In D. W. Nangle \& C. A. Erdley. The role of friendship in psychological adjustment (pp. 79-92). Jossey-Bass Publishers

Djukanović, I., Sorjonen, K., \& Peterson, U. (2015). Association between depressive symptoms and age, sex, loneliness and treatment among 
older people in Sweden. Aging \& mental health, 19(6), 560-568. https://doi.org/10.1080/13607863.2014.962001

Elboj, C. E., Puigdellivol, I., Soler, M., \& Valls, R. (2003). Comunidades de aprendizaje: transformar la educación. Graó.

Erikson, E. H. (1982). The life cycle completed. WW Norton \& Company. Erikson, E. H., \& Erikson, J. M. (1998). The life cycle completed (extended version). WW Norton \& Company.

Flecha, R. (2000). Sharing words: Theory and practice of dialogic learning. Rowman \& Littlefield.

Flecha, R. (2015). Successful educational actions for inclusion and social cohesion in Europe. Springer.

Folgueiras, P. (2011). Las comunidades de aprendizaje: la escuela de adultos de la Verneda. Una experiencia de comunidades de aprendizaje. Tendencias pedagógicas, 18, 251-267. Portal de revistas electrónicas de la UAM, https://revistas.uam.es/tendenciaspedagogicas/article/view/1995

Fortenbaugh, W. W. (1975). Aristotle's analysis of friendship: Function and analogy, resemblance, and focal meaning. Phronesis, 20(1), 51-62. https://doi.org/10.1163/156852875X00157

Gerino, E., Rollè, L., Sechi, C., \& Brustia, P. (2017). Loneliness, resilience, mental health, and quality of life in old age: A structural equation model. Frontiers in psychology, 8.

https://doi.org/10.3389/fpsyg.2017.02003

Gómez, A., Puigvert, L., \& Flecha, R. (2011). Critical Communicative Methodology: Informing Real Social Transformation Through Research. Qualitative Inquiry, 17(3), 235245. https://doi.org/10.1177/1077800410397802

Gómez, G., Siles, G., \& Tejedor, M. (2012). Contribuyendo a la transformación social a través de la metodología comunicativa de investigación. Qualitative Research in Education, 1(1), 36-57.

Jones, L. G. (1987). The Theological Transformation of Aristotelian Friendship in the Thought of St. Thomas Aquinas. The New Scholasticism, 61(4), 373-399.

https://doi.org/10.5840/newscholas19876141

Kendrick, K., Jutengren, G., \& Stattin, H. (2012). The protective role of supportive friends against bullying perpetration and victimization. Journal of adolescence, 35(4), 1069-1080. https://doi.org/10.1016/j.adolescence.2012.02.014 
Lane, R. E. (2000). The loss of happiness in market democracies. Yale University Press.

Leibowitz, U. D. (2018). What is Friendship? Disputatio, 10(49), 97-117. https://doi.org/10.2478/disp-2018-0008

McCall, G., McCall, M. M., Denzin, N. K., Suttles, G. D. \& Kurth, S. B. (2017). Friendship as a Social Institution. Routledge.

Mollenkopf, H., Marcellini, F., Ruoppila, I., Flaschenträger, P., Gagliardi, C., \& Spazzafumo, L. (1997). Outdoor mobility and social relationships of elderly people. Archives of gerontology and geriatrics, 24(3), 295-310. https://doi.org/10.1016/S01674943(97)00781-4

Ney, P. (2006). Charity as the Perfection of Natural Friendship in Aquinas' Summa Theologiae. LURJ. Lethbridge Undergraduate Research Journal, https://lurj.org/issues/volume-1-number-1/aquinas

Puigvert, L., Christou, M. \& Holford, J. (2012) Critical Communicative Methodology: including vulnerable voices in research through dialogue, Cambridge Journal of Education, 42(4), 513-526. https://doi.org/10.1080/0305764X.2012.733341

Putnam, R. D. (2001). Bowling Alone: The Collapse and Revival of American Community. 1st. Simon \& Schuster.

Racionero, S. (2018). Relaciones humanas de calidad como contexto de salud y libertad. Revista de Fomento Social, 73(289). https://dialnet.unirioja.es/servlet/articulo?codigo=6220963

Redondo-Sama, G. (2015). Dialogic leadership in learning communities. Intangible Capital, 11(3), 437-457.

https://doi.org/10.3926/ic.651

Reisman, J. M. (1979). Anatomy of friendship. Ardent Media, Irvington Publishers.

Ríos, O., Herrero, C., \& Rodríguez, H. (2013). From access to education: The revolutionary transformation of schools as learning communities. International Review of Qualitative Research, 6(2), 239-253. https://doi.org/10.1525/irqr.2013.6.2.239

Rodriguez-Laso, A., Zunzunegui, M. V., \& Otero, A. (2007). The effect of social relationships on survival in elderly residents of a Southern European community: a cohort study. BMC geriatrics, 7(1), 19. https://doi.org/10.1186/1471-2318-7-19

Sabin, E. P. (1993). Social relationships and mortality among the elderly. Journal of Applied Gerontology, 12(1), 44-60. https://doi.org/10.1177/073346489301200105 
Sánchez, M. (1999). La Verneda-Sant Martí: A school where people dare to dream. Harvard educational review, 69(3), 320-335. Harvard Education Publishing Group. https://www.hepg.org/herhome/issues/harvard-educational-review-volume-69-issue3/herarticle/_157

Schwartz, D. (2007). Aquinas on friendship. Oxford University Press.

Serrano, M. A., Mirceva, J., \& Larena, R. (2010). Dialogic imagination in literacy development. Revista de Psicodidáctica, 15(2), 191-205. https://doi.org/10.1387/RevPsicodidact.820

Shushok Jr, F. (2008). Learning friendship: The "indispensable basis of a good society". About Campus, 13(3), 19-26. https://10.1002/abc.254

Soler, M. (2015). Biographies of "Invisible" People Who Transform Their Lives and Enhance Social Transformations Through Dialogic Gatherings. Qualitative Inquiry, 21(10), 839-842. https://doi.org/10.1177/1077800415614032

Steptoe, A., Shankar, A., Demakakos, P., \& Wardle, J. (2013). Social isolation, loneliness, and all-cause mortality in older men and women. Proceedings of the National Academy of Sciences of the United States of America, 110(15), 5797-5801. https://doi.org/10.1073/pnas.1219686110

Stake, R. E. (2005). Qualitative Case Studies. In N. K. Denzin \& Y. S. Lincoln (Ed.), Strategies of Qualitative Inqury (pp. 443-466). Sage Publication.

Stern-Gillet, S. (1995). Aristotle's philosophy of friendship. State University of New York Press.

Tabak, B. A., Mccullough, M. E., Luna, L. R., Bono, G., \& Berry, J. W. (2012). Conciliatory Gestures Facilitate Forgiveness and Feelings of Friendship by Making Transgressors Appear More Agreeable. Journal of personality, 80(2), 503536. https://doi.org/10.1111/j.1467-6494.2011.00728.x

Thomas, L. (1987). Friendship. Synthese, 72(2), 217-236. https://doi.org/10.1007/BF00413639

Thomas, L. (2013). The Character of Friendship. In D. Caluori (Ed.), Thinking about Friendship: Historical and Contemporary Philosophical Perspectives (pp. 30-44). Palgrave Macmillan.

Thomson, D. M. H., \& Crocker, C. (2013). A data-driven classification of feelings. Food Quality and Preference, 27(2), 137152. https://doi.org/10.1016/j.foodqual.2012.09.002 
Vaillant, G. E. (2003). Aging well: Surprising guideposts to a happier life from the landmark study of adult development. Little, Brown.

Valls, R., \& Munté, A. (2010). Las claves del aprendizaje dialógico en las Comunidades de Aprendizaje. Revista interuniversitaria de formación del profesorado, 24(1), 11-15. https://www.redalyc.org/articulo.oa?id=274/27419180001

Vitaro, F., Boivin, M., \& Bukowski, W. M. (2009). The role of friendship in child and adolescent psychosocial development. In K. H. Rubin, W. M. Bukowski, \& B. Laursen (Eds.), Social, emotional, and personality development in context. Handbook of peer interactions, relationships, and groups (pp. 568-585). The Guilford Press.

White, R. (1999). Friendship: Ancient and modern. International Philosophical Quarterly, 39(1), 19-34. https://doi.org/10.5840/ipq199939163

Wilhelmson, K., Andersson, C., Waern, M., \& Allebeck, P. (2005). Elderly people's perspectives on quality of life. Ageing \& Society, 25(4), 585-600. https://doi.org/10.1017/S0144686X05003454 Zamora, J. M. (Ed.) (2009). La Amistad en la Filosofía Antigua. UAM Ediciones.

Susana León-Jiménez is a FPU research and teaching fellow from the Spanish Government at the Department of Sociology, Faculty of Economics and Business of the University of Barcelona. https://orcid.org/0000-0001-8587-7028

Contact Address: Avda. Diagonal, 690-696 08034 Barcelona Tel. +34934021801 